\title{
The Relationship between Career Preparation Behavior and Career Decision Attitudes among Adolescent Sports Players
}

\author{
Chun-Ho Yang, Professor, Dept. of Marine Sports, 46 Hanseo 1-ro, Haemi-Myun, Seosan-Si, \\ Chungcheognam-do, Hanseo University, 31962, Korea, healthyang@hanseo.ac.kr \\ *Corresponding Author
}

\begin{abstract}
This research was performed to examine the relationship between career preparation behavior and career decision attitudes among adolescent student sports players. In this study, the survey respondents were asked to fill out the questionnaire, and the copies of the questionnaire were collected immediately after being completed by the respondents. In the event of excluding some copies which were not sincerely filled out, 389 copies in total were used for the final analysis. The results reached through research process are as follows. First, this research showed that career preparation behavior has a positive relationship with career decision attitudes among students. In this way, the career preparation behavior has significant positive effects on career preparation attitudes. Third, career preparation behavior has significant positive effects on career maturity of students. Forth, career preparation behavior has significant positive effects on the determining of a suitable career decision level of the students. In conclusion, the necessity to do career preparation behavior is an important step to take before deciding one's career. In short, this research seems to evidence that we need to do career education, in an effort to help adolescent student sports players to decide their future careers.
\end{abstract}

Keywords: Adolescent student sports players, Career preparation behavior, Career preparation attitudes, Career maturity, Career decision level.

Received: 04.12.2020 $\quad$ Accepted: 17.01.2021 $\quad$ Published: 02.02.2021

\section{INTRODUCTION}

While adolescents in modern society have diverse kinds of angst, what is the most decisive and affects their lives for a long time is agony over the decision to choose their careers after their high school education [1]. Unlike the case in the past, jobs that are available now in the modern society are more meaningful as the means to display one's ability and talent, even more than just as the means to make money to survive. Through the process of figuring out one's ability and talent, and preparing for the job suitable to one's ability and talent, one can rationally choose one's career [2]. In particular, in the case of adolescent sports players, career decision is very important to the choice of a future job.

Except for some excellent adolescent players, most of these students who are not very good at their sports and who have low school grades, will have some difficulty in finding jobs not to mention later entering college. Accordingly, in the college entrance season, they are worried about their future if they are seen not to measure up to the performance of their peers [3,4]. Sports players in Korean high school spend their hours preparing for competitive games, and for this reason they are isolated from the process of school learning to enter college and technology to find jobs. In fact, while some adolescent sports players become famous, thousands of other players drop in the middle way of job hunting after school years are over [5].

There are various theories on how these students find a career. In the perspective of a career, one's life is not determined at a specific moment, but formed in the course of development for a long time [6]. This study, by examining career preparation behavior and career decision attitudes of adolescent sports players, wants to provide basic resources to help them find out their careers.

Career preparation behavior is the inclusion of all the activities for their future jobs such as acquiring licenses, collection of job information, preparation of tools needed in achieving career goals, and other activities they invest time and efforts to achieve career goals. Career preparation behavior is not a review of cognitive or attitudinal dimensions related with career, but practical concrete behavior used to find a suitable career for these students [4]. While career preparation behavior is the most basic and concrete behavior for a career, what adolescent sports players do will have very little effect on such a behavior.

It is true that though those student sports players are worried much about their futures, they do not know how to prepare for them. As they experience difficulties in relationships with friends and 
school life more than common students, they have more difficulties in career preparation than other students. It is evidenced by research $[7,8]$ which revealed that student sports players get more stress than common students on their futures, that is, job finding and a career. What is more problematic is the fact that while they pay attention to and are worried about their futures, they do few things to advance on them.

In general, the idea of making a career decision is important to adolescent sports players. Depending on how they decide on their futures, their values and attitudes as well as life patterns change, and, ultimately, it can be an important factor deciding their success in life $[9,10]$. Career decision means the full consideration of career decision process, career preparation, personal characteristics, facing development problem, and decision-making situation, and understanding personal variables affecting career preparation and career decision attitudes [11]. Such a problem of career decision is not limited to an individual, but can have great effect on development of adolescents in a general sense [12]. To adolescent sports players, the career problem is what they should think of the most seriously, and need to resolve this problem to find a job after high school has ended [13]. Therefore, by examining the relationship between career preparation behavior and career decision attitudes among adolescent sports players, this study wants to provide basic resources to help them discover and develop possibilities they possess and understand employment situation, future prospect, parental expectation, and job ethics. To achieve such research aims, this study set the following questions. First, is there any relationship between career preparation behavior and career decision attitudes among adolescent sports players? Second, will career preparation behavior affect career decision attitudes?

\section{Research Methods}

\subsection{Research objects}

The objects of this research are adolescent sports players registered in the Korean Sports \& Olympic Committee in 2019. Using convenience sampling method, this research selected 400 adolescent sports players, and performed a study sending a survey to them. Survey respondents were asked to fill out the questionnaire, and the copies of the questionnaire were collected immediately after they filled it out. Excluding some copies which were not sincerely filled out, there were 389 copies in total were used for final analysis. The general characteristics of the respondents are shown in [Table 1].

Table 1: General characteristics of respondents

\begin{tabular}{llll}
\hline Variable & Classification & $\begin{array}{l}\text { Frequency } \\
(\mathrm{n})\end{array}$ & Percentage (\%) \\
\hline \multirow{2}{*}{ Gender } & Male & 251 & 64.5 \\
& Female & 138 & 35.5 \\
\hline \multirow{2}{*}{ Year } & Middle school & 195 & 50.1 \\
& High school & 194 & 49.9 \\
\hline \multirow{3}{*}{ School year } & $1^{\text {st }}$ grade & 104 & 26.7 \\
& $2^{\text {nd }}$ grade & 152 & 39.1 \\
& $3^{\text {rd }}$ grade & 133 & 34.2 \\
\hline \multirow{2}{*}{ Sports } & Individual event & 95 & 24.4 \\
category & Man-to-man & 109 & 28.0 \\
& event & 185 & 47.6 \\
\hline & Team event & & 100 \\
\hline
\end{tabular}

\subsection{Survey tools}

\subsubsection{Career preparation behavior}

The survey tool to measure career preparation behavior was the revised version of what Cha [14] developed to test career preparation behavior. In general, the tool consisted of the following questions: career efforts ( 3 questions), career consultation (3 questions), and career exploration (3 questions) $[15,16,17]$. Respondents were asked to choose their answers from the Likert scale ranging from 'Definitely no' (1 point), 'No' (2 points), 'So so' (3 points), 'Yes' (4 points), to 'Definitely yes' (5 points).

\subsubsection{Career decision attitudes}

This research revised the career decision test developed by Osipow [18] to fit the aims of this research. 
The tool consisted of questions on career preparation attitudes (4 questions), career maturity (4 questions), and career decision level (4 questions) $[19,20,21]$. Here the respondents were asked to choose their answers from the Likert scale ranging from 'Definitely no' (1 point), 'No' (2 points), 'So so' (3 points), 'Yes' (4 points), to 'Definitely yes' (5 points).

\subsection{Validity and reliability}

To test validity of the survey tools, this research performed a principal component analysis of exploratory factor analysis. To simplify factor construct, this research used varimax among orthogonal rotation methods [22]. The criteria to extract common variances was eigenvalue 1.0 or over. Accordingly, the variables included in the factor were those with factor loading .50 or over. To test reliability of survey tools, this research used Cronbach's $\alpha$ coefficient following the standard of internal consistency [23].

\subsubsection{Career preparation behavior}

Table 2: Validity and reliability of career preparation behavior

\begin{tabular}{|c|c|c|c|c|}
\hline Q No. & Career efforts & Career consultation & Career exploration & $\mathrm{h}^{2}$ \\
\hline Q 1 & .918 & .085 & .071 & .694 \\
\hline Q 2 & .906 & .081 & .121 & 655 \\
\hline Q 3 & .723 & -.007 & .158 & .398 \\
\hline Q 4 & .102 & .821 & .054 & .842 \\
\hline Q 5 & .188 & .797 & .079 & .855 \\
\hline Q 6 & -.166 & .719 & .249 & .548 \\
\hline Q 7 & .089 & .046 & .827 & 677 \\
\hline Q 8 & .089 & 152 & .790 & 688 \\
\hline Q 9 & 140 & .125 & .602 & .606 \\
\hline Eigenvalue & 2.895 & 1.807 & 1.260 & \\
\hline Variance\% & 32.169 & 20.075 & 14.003 & \\
\hline Cumulative \% & 32.169 & 52.244 & 66.247 & \\
\hline Reliability & .774 & .861 & .717 & \\
\hline \multicolumn{5}{|c|}{$\mathrm{KMO}=.691, \chi^{2}=1114.055, \mathrm{df}=36, \mathrm{p}=.001$} \\
\hline
\end{tabular}

As shown in [Table 2], the Bartlett identity matrix of career preparation behavior was 21114.055, and significance probability was .001, and KMO index was .691, showing that selection of variables was proper. Here, the factor analysis of 9 questions extracted 3 factors, which explained $66.2 \%$ of total variate. Next, it is noted that the factor loadings of career efforts, sub-factor of career preparation behavior were .723 .918, those of career consultation were .719 .821, and those of career exploration were .602 .827. Likewise, the reliability values for 3 factors were as follows: .744 for career efforts, .709 for confidence on future, .861 for career consultation, and .717 for career exploration. Broadly speaking, all of these results were determined to be reliable..

\subsubsection{Career decision attitudes}

Table 3: Validity and reliability of career decision attitudes

\begin{tabular}{|c|c|c|c|c|}
\hline Q No. & Career decision attitudes & Career maturity & Career decision level & $\mathrm{h}^{2}$ \\
\hline Q 07 & .937 & -.051 & .061 & .615 \\
\hline Q 06 & .932 & .006 & .016 & .694 \\
\hline Q 08 & .920 & -.043 & .086 & .618 \\
\hline Q 05 & .854 & .072 & .037 & .687 \\
\hline Q 11 & -.009 & .871 & -.073 & .736 \\
\hline Q 09 & .022 & .842 & -.065 & .869 \\
\hline Q 12 & .033 & .839 & -.095 & .884 \\
\hline Q 10 & -.054 & .812 & -.026 & .855 \\
\hline Q 03 & .023 & -.094 & .713 & .713 \\
\hline Q 02 & .112 & -.069 & 690 & .664 \\
\hline Q 04 & .014 & .030 & .621 & .765 \\
\hline Q 01 & .007 & -.073 & .556 & .714 \\
\hline
\end{tabular}




\begin{tabular}{llll}
\hline Eigenvalue & 3.408 & 2.936 & 1.569 \\
Variance $\%$ & 28.403 & 24.469 & 13.071 \\
Cumulative $\%$ & 28.403 & 52.872 & 65.943 \\
\hline Reliability & .771 & .836 & .900 \\
\hline KMO $=.795, \chi^{2}=2329.294, \mathrm{df}=66, \mathrm{p}=.001$ & & \\
\hline
\end{tabular}

As shown in [Table 3], the Bartlett identity matrix of career decision attitudes was 2329.294, and significance probability was .001, and KMO index was .795, showing that selection of variables was proper. It was determined that the factor analysis of 12 questions of career decision attitudes extracted 3 factors, which explained $65.9 \%$ of total variate. Next the factor loadings of career preparation attitudes, sub-factor of career decision attitudes were .854 .937, those of career maturity were $.812 \sim .871$, and those of career decision level were .556 .713. Specifically, the reliability values for 3 factors were as follows: .771 for career preparation attitudes, .836 for career maturity, and .900 for career decision level. All of these results in general were determined to be reliable.

\subsection{Data treatment}

In this study, the collected data were analyzed using the SPSS (ver 21.0) program. The collected data were under a descriptive statistics analysis, exploratory factor analysis, and reliability analysis to identify normal distribution, validity, and reliability. To examine relations among variables, this research performed correlation analysis, and, to examine causal relations among variables, it performed multiple regression analysis. Finally, it was noted that the significance level was set at $\alpha=.05$.

\section{Research findings}

3.1. Correlation between career preparation behavior and career decision attitudes among adolescent sports players

Table 4: Correlation between career preparation behavior and career decision attitudes

\begin{tabular}{lllllll}
\hline Variable & $\mathrm{A}$ & $\mathrm{B}$ & $\mathrm{C}$ & $\mathrm{D}$ & $\mathrm{E}$ & $\mathrm{F}$ \\
\hline Career efforts & - & & & & & \\
Career consultation & $.263^{* * *}$ & - & & & & \\
Career exploration & $.295^{* * *}$ & $.134^{* *}$ & - & & & \\
Career preparation attitudes & $.346^{* * *}$ & $.544^{* * *}$ & $.278^{* * *}$ & - & & \\
Career maturity & .044 & $.139^{* *}$ & $.190^{* * *}$ & $.112^{*}$ & - & \\
Career decision level & $.100^{*}$ & $.315^{* * *}$ & .062 & $.158^{* *}$ & -.012 & - \\
\hline
\end{tabular}

$<.001,{ }^{* *} \mathrm{p}<.01,{ }^{*} \mathrm{p}<.05$

The correlations between career preparation behavior and career decision attitudes are as follows [Table 4]. In this context, the career efforts are positively correlated with career preparation attitudes $(\mathrm{r}=.346)$ and Career decision level $(\mathrm{r}=.100)$. In other words, the career consultation with career preparation attitudes $r=.544)$, career decision level $(r=.278)$, and career maturity $(r=.190)$ were reviewed and analyzed.

\subsection{Relationship between career preparation behavior and career decision attitudes among adolescent sports players}

\subsubsection{Relationship between career preparation behavior and career preparation attitudes}

Table 5. Relationship between career preparation behavior and career preparation attitudes

\begin{tabular}{lllllll}
\hline & $\mathrm{B}$ & $\mathrm{SE}$ & Beta & $t$ & tolerance & VIF \\
\hline Constant & .820 & .155 & & $5.301^{* * *}$ & & \\
Career efforts & .152 & .039 & .172 & $3.927^{* * *}$ & .862 & 1.160 \\
Career consultation & .366 & .032 & .477 & $11.311^{* * *}$ & .927 & 1.078 \\
Career exploration & .134 & .035 & .164 & $3.839^{* * *}$ & .910 & 1.099 \\
\hline $\mathrm{R}^{2}=.365$, Corrected $\mathrm{R}^{2}=.360, \mathrm{~F}=73.643^{* * *}$ & & & & \\
\hline
\end{tabular}


$<.001$

In this context, the career preparation behavior has statistically significant effect on career preparation attitudes $(\mathrm{F}=73.643, \mathrm{p}<.001)$. Its explanatory power was $36.5 \%\left(\mathrm{R}^{2}=.365\right)$ of all the reviewed variate. It is noted that the Beta values, which are relative effects of variables belonging to career preparation behavior factor on career preparation attitudes were as follows: career efforts $(\beta=.172, p<.001)$, career consultation $(\beta=.477, p<.001)$, and career exploration $(\beta=.164, p<.001)$ [Table 5]. That is, all the variables belonging to the career preparation behavior factor are positively correlated with career preparation attitudes.

\subsubsection{Relationship between career preparation behavior and career maturity}

Table 6. Relationship between career preparation behavior and career maturity

\begin{tabular}{lllllll}
\hline & $\mathrm{B}$ & SE & Beta & $t$ & tolerance & VIF \\
\hline Constant & 2.706 & .289 & & $9.362^{* * *}$ & & \\
Career efforts & .098 & .072 & .072 & 1.359 & .862 & 1.160 \\
Career consultation & .178 & .060 & .151 & $2.954^{* *}$ & .927 & 1.078 \\
Career exploration & .293 & .065 & .231 & $4.478^{* * *}$ & .910 & 1.099 \\
\hline $\mathrm{R}^{2}=.068$, Corrected $\mathrm{R}^{2}=.061, \mathrm{~F}=9.351^{* * *}$ \\
\hline$<.001,{ }^{* *} \mathrm{p}<.01$
\end{tabular}

In this case, the career preparation behavior has statistically significant effect on career maturity $(\mathrm{F}=73.643, \mathrm{p}<.001)$. Its explanatory power was $6.8 \%\left(\mathrm{R}^{2}=.068\right)$ of all the noted variate. In this sense, the Beta values, which are relative effects of variables belonging to career preparation behavior factor on career maturity were as follows: career consultation $(\beta=.151, p<.01)$, and career exploration $(\beta=.231$, $\mathrm{p}<.001$ ) [Table 6]. That is, the career consultation and career exploration have positive effects on career maturity.

\subsubsection{Relationship between career preparation behavior and career decision level}

Table 7. Relationship between career preparation behavior and career decision level

\begin{tabular}{lllllll}
\hline & $\mathrm{B}$ & $\mathrm{SE}$ & Beta & $t$ & tolerance & VIF \\
\hline Constant & 3.514 & .241 & & $14.582^{* * *}$ & & \\
Career efforts & .213 & .060 & .180 & $3.530^{* * *}$ & .862 & 1.160 \\
Career consultation & .379 & .050 & .370 & $7.525^{* * *}$ & .927 & 1.078 \\
Career exploration & .064 & .054 & .058 & 1.178 & .910 & 1.099 \\
\hline $\mathrm{R}^{2}=.138$, Corrected $\mathrm{R}^{2}=.131, \mathrm{~F}=20.531^{* * *}$ & & & &
\end{tabular}

<.001

In this respect, the career preparation behavior has statistically significant effect on career decision level $(\mathrm{F}=20.531, \mathrm{p}<.001)$. Its explanatory power was $13.8 \%\left(\mathrm{R}^{2}=.138\right)$ of all the noted variate. It was shown that the Beta values, which are relative effects of variables belonging to career preparation behavior factor on career maturity were as follows: career efforts $(\beta=.180, p<.001)$, and career consultation $(\beta=.370, p<.001)$ [Table 7]. That is, it is shown that career efforts and career consultation have positive effects on career decision levels.

\section{Discussion}

This research was performed to examine the relationship between career preparation behavior and career decision attitudes among adolescent student sports players. Based on the findings of this research, the following discussions can be determined.

This research showed that career preparation behavior has positive relationship with career decision attitudes. A multiple regression analysis showed that career preparation behavior has significant positive effects on career preparation attitudes, career maturity, and career decision levels.

In general, it is shown that such findings are consistent with those of a study [24] proving that 
career preparation behavior has significant positive effects on career preparation attitudes, and career decision level among college sports players. It is also noted that another study [25] is offered proving that career preparation behavior has significant positive effects on career preparation attitudes, and career decision level among high school students applying for physical education departments. The findings of this research are also supported by a research study, showing that those who are high in self efficacy in career decision are also high in career maturity [26]. The findings of this research and similar findings of other researchers mean that it is necessary to make efforts to develop strategies to deal with results of career preparation, and to prevent negative results regarding the choosing of a career among adolescent student sports players.

In general, individuals are conscious of and explore their future careers, and, at the same time, plan and prepare for them. In short, career decision is made through complex processes, and career preparation behavior has positive affect on clear goals of preparation and individual independence. The overall decision on career direction and exploration of career to choose future jobs are very important factors to be determined in the career decision process [27]. One of the most important methods to raise career decision attitudes of adolescent sports players, is to make efforts on career based on consultation and exploration on career of those players. In short, desirable career decision attitudes are the results achieved career preparation efforts, which will be based on career design and plans through career education for these students while they are in school to assist them for a long time after graduation. To rationally decide a future career at a crucial time to decide career, it is important to establish career decision attitudes early on, such as in high school.

The reason why adolescent sports players cannot decide their future careers seemed to be caused by a fundamental lack of understanding of themselves, lack of consciousness and information on career, and fear of choice. Consequently, it is necessary to help them to make the best decisions, and to support them to behave in a way to discover themselves and explore careers, and prepare for choosing college departments suitable for their aptitudes, and decide on their future careers matching their career decisions.

\section{Conclusion}

In conclusion, this research was performed to examine the relationship between career preparation behavior and career decision attitudes among adolescent student sports players. The conclusions reached through research process are as follows. First, this research showed that career preparation behavior has positive relationship with the career decision attitudes of these students reviewed. In this way, career preparation behavior has significant positive effects on their career preparation attitudes. Third, career preparation behavior has significant positive effects on career maturity for these students. And fourth, career preparation behavior has significant positive effects on the career decision level of these types of students as they choose a suitable career.

Such results prove the necessity to do career preparation behavior before deciding one's career. In short, this research seems to evidence that we need to do career education to help adolescent student sports players, which will go a long way to helping them to make good decisions to decide their future careers going forward.

\section{Acknowledgments}

This study was from the 2020 Academic Research Support Project of Hanseo University.

\section{References}

[1] Kim JU, Kang JI.(2009) The Effect of Perceived Parenting Attitudes by Teenagers and Their Psychological Separation on Career Decision-Making Level. The Journal of Career Educational Research 22(3):121-135

[2] Lee HJ, Lee YK.(2014) Research on Major Satisfaction and Employment Sense of Dance Major University Students. Official Journal of Korean Society of Dance Science 14:31(2):17-33.

[3] Moon HJ, Lee SH.(2010) Effects of Athletic Experience Characteristics and Self-Management on the Level of Career Decision Making among High-school Student Athletes. Journal of Sport and Leisure Studies 42: 559-570.

[4] Jeon YM.(2019) A Study on the Causes of Education Probation and the Effects of a Supporting Program for Low Achieving Students at University. The Journal of Korea Open Association for Education

27(4):51-73.

[5] Yim YS, Han MS, Kim JS.(2014) The Path-Analysis of Student Athletes` Drop-Out. Korean Journal of 
Sport Science 25(3):450-466.

[6] Lee JC.(2013) Theoretical Study and Comparison Analysis of Research Results on the Career Decision Self-Efficacy of University Students. Journal of Employment and Career 3(1):49-66.

[7] Kim BW.(2010) The Relationship of Resilience, Career Attitude Maturity and Career Preparation Behavior of College Woman. Career Education Research 23(4):93-111.

[8] Kim MJ, Park SY.(2017) The Relation between General Self-Efficacy and Career Preparation Behavior, Perceived Career Barrier: Mediating Effects of Career Decision-Making Self-Efficacy. The Journal of Career Educational Research 30(1):162-180.

[9] Jeong EI.(2018) Effects of Career Decision-Making Difficulties on College Students' Counseling Attitude and Intention. Journal of learner-centered curriculum and instruction 18(15):447-470.

[10] Seo HJ, Lim SW, Jeon WJ.(2018) The Challenges and Coincidental Events for Career Exploration Experience of Drop-Out High School Student Athletes. Korean Journal of Sociology of Sport 31(1):149-170.

[11] Kim HS, Kim OH.(2008) The study on the path model of support level, stress, self-concept and career development. The Journal of Career Education Research 21(1):77-94.

[12] Lee, YK, You JA, Lee HS.(2017) An Analysis of Career Decision Type and Career Decision Level of Student-Athletes in Secondary School. Korean Journal of Sport Pedagogy 24(1):1-16.

[13] Kim YH, Kim KE, Choi JH.(2011) Career decision-making styles and career maturity amongst Korean undergraduate students. Journal of the Korea Academia-Industrial cooperation Society 12(3):12231233.

[14] Cha YS.(2009) Career Decision and Career Preparation Behavior in the Students Who want to Enter the Universities Related to Physical Education. Unpublished master's Dissertation. Chungang University $13 \mathrm{p}$.

[15] Son EY, Kim YJ.(2010) The Relationship between Learning Behaviors and Two Dimensional Typology in Career Decision Making Level and Career Preparation Behavior among College Students. The Journal of Career Educational Research 23(4):1-20.

[16] Kim MH, Choi, WY.(20142) The Influence of Career Barriers perceived by General Female High School Student, Career dicision-making self-efficacy, Career outcome expectation on Career Preparation Behavior: The Mediating Effects of Career Aspiration. The Journal of Career Educational Research 27(1):83-107.

[17] Ko GP, Sim MY.(2014) The Structural Relation of Self-efficacy, Job Stress, Career Maturity and Career Preparation Behavior of College Students. The Journal of Career Educational Research 27(1):19-38.

[18] Osipow SH.(1999) Assessing career indecision. Journal of Vocational Behavior 55:147-154.

[19] Kim YH, Lee WG.(2017) Adolescents' Career Decision and Stress: The Effects of Parenting Styles and Adolescents' Motivation. The Korea educational review 23(4):183-204.

[20] Yoo YR.(2010) The effect of intolerance of uncertainty, self-efficacy and attitude of career decision making in college dance student. The Korean journal of dance studies 30:115-138.

[21] Park JY.(2018) The Influence of Youth's Resilience and Social Support On Self-Efficacy Regarding Career Decision-Making and Career Attitude Maturity. The Korean Society Of School Social Work 42:187-208.

[22] Lim JS, Oh YP, Yang CH.(2016) Effects of University Student Players' Achievement Goal Orientations on Career Maturity and Career Exploratory Behaviors. The Korean Journal of Sport 14(3):55-65.

[23] Lim JS, Yang CH.(2014) Relationships between Marine Sports Participants' Exercise Adherence and Interpersonal Orientation and Their Exercise Desire. The Korean Journal of Sport 12(3):325-336.

[24] Yoo DH, Yeo IS, Ahn BW.(2011) The influence of Life-style on Career Decision Level and Career Preparation Behavior in the Collegiate Athletes. Journal of Sport and Leisure Studies 46(1):773-784.

[25] Kim YJ, Yang WY, Cha YS. (2012) The Effect of Perceived Career Barriers on The Career Decision Level of The Examinee of Physical Education Department. The Korea Journal of Sport 10(2):221-230.

[26] Jo HI, Lee YJ, Oh SH, Kim KM.(2012) The Influence of Exercise Stress on Careers Decision-Making Self-Efficacy, and Vocational Maturity of High School Bowling Players. Korean journal of sports science 21(2):159-173.

[27] Kim KW.(2016) Career Decision-Making Self-Efficacy and Career Exploration Behavior by Sports Career of Student Boxers. The official journal of the Korean association of certified exercise professionals 18(3):35-42. 